\title{
Os novos movimentos de protesto em França. A articulação de novas arenas públicas
}

The new protest movements in France. The articulation of new public arenas Les nouveaux mouvements de protestation en France. L'articulation de nouvelles arènes publiques

\section{Daniel Cefaï}

Tradutor: Maria do Rosário Mariano

\section{OpenEdition}

\section{Journals}

Edição electrónica

URL: http://journals.openedition.org/rccs/985

DOI: $10.4000 /$ rccs. 985

ISSN: 2182-7435

\section{Editora}

Centro de Estudos Sociais da Universidade de Coimbra

\section{Edição impressa}

Data de publição: 1 Outubro 2005

Paginação: 129-160

ISSN: 0254-1106

\section{Refêrencia eletrónica}

Daniel Cefaï, «Os novos movimentos de protesto em França. A articulação de novas arenas públicas », Revista Crítica de Ciências Sociais [Online], 72 | 2005, colocado online no dia 01 outubro 2012, criado a 03 maio 2019. URL : http://journals.openedition.org/rccs/985 ; DOI : 10.4000/rccs.985 


\section{DANIEL CEFAÏ}

\section{Os novos movimentos de protesto em França A articulação de novas arenas públicas}

Este artigo traça um panorama crítico da emergência dos novos movimentos de protesto (NMP) em França, nas últimas décadas. Argumenta-se que desde meados dos anos oitenta, novas arenas públicas foram abertas pelos NMP, seguindo as transformações da sociedade salarial e da política pública, e respondendo à mundialização crescente dos mecanismos económicos, estratégicos e sociais. Para quem investe politicamente nos NMP, a importância da sua emergência reside no rearmamento da crítica social e na reconstituição de uma esquerda radical. Novos problemas públicos se impuseram aos cidadãos, aos especialistas e aos decisores políticos, em particular em torno da questão dos "sem documentos", dos "sem trabalho" e dos "sem abrigo" mas também da saúde pública, da ecologia ou do consumo. Novos actores colectivos, ONGs, movimentos e coordenações tornaram-se os parceiros e os adversários incontornáveis dos poderes públicos. Contudo, alerta-se para o perigo destes movimentos resvalarem para uma acção político-partidária institucional, que poria em causa a acção concertada da esquerda política e a eficácia da sua actuação quer no contexto nacional quer no contexto europeu.

Este artigo $^{1}$ traça um panorama da geração de novos movimentos de protesto - que qualificaremos por comodidade como NMP - que emergiu em França desde meados dos anos oitenta (Sommier e Crettiez, 2002; Sommier, 2003). Com a sigla NMP não pretendemos reproduzir o mito de um "sujeito colectivo" análogo ao dos novos movimentos sociais (NMS) dos anos setenta.

Trata-se apenas de encontrar traços comuns entre diferentes organizações associativas, que amiúde participam nos Fóruns sociais, e cujos membros circulam entre de uma para a outra e se coligam, de modo mais ou menos informal, numa galáxia da contestação qualificada como "esquerda da esquerda" (Pingaud, 2000).

Estes NMP tiveram, a nosso ver, um lugar crucial na vida social e política de há cerca de vinte anos para cá. Eles participaram numa renovação das práticas militantes, forjaram novas perspectivas sobre o bem público e desen-

\footnotetext{
${ }^{1}$ Uma primeira versão deste texto foi apresentada no colóquio Acção colectiva, espaço público e cidadania, organizado por José Manuel Mendes em Coimbra, em Janeiro de 2005.
} 
volveram novos cenários de acção pública - em particular as dos "alter" e as dos "sem". Assim, ganharam uma visibilidade notável na opinião pública e uma verdadeira legitimidade junto dos poderes públicos. Reúnem toda a espécie de partidos e de sindicatos, ONGs e associações, movimentos e coligações que se situam no xadrez político à esquerda da aliança da defunta "esquerda plural" - PS, PC e Verdes, no governo do período entre 1997 e 2002. Além disso, mantêm, do ponto de vista das reivindicações, dos líderes e das organizações, relações de herança e de demarcação bastante complexas com a extrema esquerda e os NMS anteriores.

Estes NMP não constituem uma "força política" unificada, mas muitos dos seus membros foram activistas no seio dos comités contra o Tratado Constitucional europeu que conduziu ao voto no Não no referendo de Maio de 2005.

Iremos mostrar aqui, entrelaçando estas hipóteses com dados factuais, o modo como novas personagens públicas emergiram, inventando formas de organização, repertórios de acção e retóricas de protesto, promovendo novos problemas sociais e impondo novas arenas públicas (Cefaï, 2002, 2003).

\section{Galáxias altermundialistas: uma dinâmica europeia e global?}

Quem é que se encontra nesta constelação dos NMP? Partidos da esquerda radical, em primeiro lugar, como a Ligue Communiste Révolutionnaire, diferentes tendências anarquistas, Globalise Résistance ou os Désobéissants, a Fédération Anarchiste ou alternative libert.

Os ecologistas fazem igualmente parte dela: os Verdes, as ONGs Greenpeace, Les Amis de la Terre, Earth First ou Reclaim the Streets. Nela se encontram também sindicatos, em particular o SUD (Solidaires, Unitaires, Démocratiques), a CNT (Confédération nacionale du travail), o G10 (Groupe des Dix), a Confédération Paysanne, ocasionalmente secções da FSU (Federation Syndicale Unitaire) e da CGT (Confédération Générale du Travail). Clubes ou grupos de reflexão, em particular a Fondation Copernic; editoras, tais como a Agone, em Marselha, ou Raisons d'Agir, em torno de Pierre Bourdieu; le Monde diplomatique, órgão crucial de coordenação e de publicitação das causas colectivas em França.

Outros agrupamentos são mais complexos, como a APEIS (Association pour l'emploi, l'information et la solidarité des chômeurs et des travailleurs précaires) e AC! (Agir contre le Chômage!), e desenvolvem acções a favor dos desempregados e trabalhadores precários e, mais amplamente, dos movimentos dos "sem" ou dos "excluídos" (Mouchard, 2001). Eles militam a favor de medidas sociais que regulamentem a situação dos sem-abrigo, dos sem-documentos e dos sem-emprego mas, globalmente, lutam contra 
a emergência de novas formas de exploração e de dominação, de estigmatização e de discriminação. A convocação dos "sem", em Dezembro de 1995, por iniciativa do $A C$ !, foi capital para forjar uma categoria dos "sem direitos". Têm como aliados mais ou menos regulares o DAL (Droit au logement), ACT UP (AIDS Coalition to Unleach Power), Droits devant!!, e os movimentos de sem-documentos, incluindo a sua franja mais universalista, como é o caso de No Border.

É necessário ainda acrescentar organizações de defesa dos direitos humanos, como a Amnistia Internacional ou a Human Rigths Watch, a LDH (Ligue des droits de l'homme) ou o GISTI (Groupe d'information et de soutien aux travailleurs immigrés). Há também ONGs humanitárias, para o desenvolvimento no Sul ou a favor do comércio equitativo, tais como Oxfam, MSF (Médecins sans frontières), o CCFD ou o CRID. Também inclui grupos de contra peritagem como o CEDETIM, Focus on the Global South, Navdanya, TWN, ISGN, URFIG, Vamos!, Fifty Years is Enough!, CCC-OMC, IFG - e, sobretudo, o mais conhecido em França, a ATTAC (Association pour une taxation des transactions financières pour l'aide aux citoyens), uma plataforma de organizações e de personalidades ligadas ao jornalismo e intelectuais que militava inicialmente a favor da taxa Tobin.

Neste últimos anos, os locais de encontro e de protesto colectivo mais marcantes foram, sem duvida, o Fórum Social Mundial e a Marcha Mundial das Mulheres, os Fóruns Sociais Europeus e as plataformas de redes electrónicas, como a Indymedia, a Samizdat e a Public Citizen.

O quadro das lutas já não é somente o do Estado-nação mas decididamente o de uma "contestação transnacional" (Tarrow, 2000). Começou-se, sem dúvida, a "pensar global, agir local" nos anos setenta e a denunciar a "nova ordem mundial". Contudo, o processo de mundialização acelerou-se posteriormente, tornando-se o motor da maioria das transformações sociais. O momento chave da internacionalização foi a contra-cimeira de protesto de Seattle, onde o entusiasmo de milhares de jovens, estudantes e militantes, lançou uma dinâmica que se confirmou em Washington DC, em Abril de 2000, e em Praga, em Setembro do mesmo ano. Um momento trágico foram os acontecimentos do anti-G7, em Génova, em Julho de 2001. Em consequência disso, o "anti-mundialismo" do No Global tornou-se uma característica central dos NMP - tendo como denominador comum a crítica ao neoliberalismo. Em França, e por iniciativa da ATTAC, ele passou a designar-se, em 2002, por alter-mundialização, para obviar à acusação de crispação nacional. Outros conservam a ideia de anti-globalização (Sommier, 2003: 30-32), referindo-se explicitamente ao poder económico e financeiro das empresas multinacionais, às políticas de exploração 
e de pilhagem dos países ricos e às normas neoliberais do Banco Mundial, do Fundo Monetário Internacional ou da Organização Mundial do Comércio (Mathieu, 1999; 2001).

Este "movimento altermundialista" é um movimento de movimentos extremamente heterogéneos (Bérout et al., 1998; Losson e Quinio, 2002), que se aliam pontualmente em torno de objectivos comuns e que se reencontram nas experimentações deliberativas dos fóruns sociais (Agrikolianski e Sommier, 2005). A sua finalidade é talvez menos criar entraves ao bom funcionamento do capitalismo mundial e federar as forças vivas de uma "nova sociedade civil mundial", do que forjar, de acordo com as suas próprias palavras, ferramentas críticas da "hegemonia cultural" do "neoliberalismo". Contra o "monopólio do pensamento único", pretende reactivar um sentido dos possíveis, quebrar o consenso que os media impõem aos cidadãos e fazer ouvir vozes alternativas.

Pretende igualmente mostrar as consequências das políticas públicas desenvolvidas em conformidade com as expectativas da WTO/OMC, as desigualdades crescentes entre países ricos e pobres, a precarização e a pauperização geradas pela especulação nos mercados financeiros ou as estratégias de restabelecimento da ordem mundial pela superpotência americana.

Enfim, tem por objectivo pôr em evidência o "matraquear ideológico" das políticas monetaristas e adeptas do mercado livre, os seus repetidos fracassos em Inglaterra ou na Argentina, bem como os seus efeitos perversos na redução dos direitos sociais, no enfraquecimento da negociação sindical, na crise da representação política, na desmoralização dos cidadãos e na escalada dos populismos e dos extremismos.

Trata-se de uma "guerra" da contra-peritagem que seria movida a fim de "libertar as consciências da sujeição neoliberal", contra as campanhas de propaganda e de desinformação, um trabalho de "descontaminação" dos media através da criação de um "quinto poder", que garanta "o direito dos cidadãos ao saber" e a "defesa da informação como bem público”. Está por elaborar uma sociologia subtil da génese destes diversos repertórios de argumentação (Wieviorka, 2003; Agrikoliansky, Fillienle e Mayer, 2005).

Em França, a ATTAC e as suas ligações complexas com o le Monde Diplomatique são fundamentais neste dispositivo. Falta ainda uma sociologia desta organização. Numerosas divergências opõem alguns dos seus líderes (Cassen, 2003) às deliberações da Assembleia europeia dos direitos das mulheres ou da Assembleia geral dos movimentos sociais. As linhas políticas de acção que contam com alavancas institucionais ou se baseiam em estratégias de radicalização extra-institucional (Aguiton, 2003) não são bem vistas. Os comités locais queixam-se do excesso de centralização parisiense 
das discussões e das decisões. Por outro lado, as sensibilidades políticas dos líderes parisienses reavivam batalhas mais antigas entre chevénementistas, comunistas, trotskistas, partidários da economia solidária ou da democracia participativa...

\section{Personagens públicas: movimentos dos sem, movimentos de mulheres}

Retorno da cena multicor dos altermundialistas à cena nacional dos movimentos dos "sem". Novas personagens públicas adquiriram visibilidade, as quais não teriam razão de ser há vinte e cinco anos. As mutações e rupturas do contrato social da sociedade salarial e do Estado-providência conduziram à emergência de novas figuras na dramaturgia da acção colectiva. O movimento de precarização e desafiliação dos assalariados (Castel, 1995) gerou novas categorias de excluídos do trabalho assalariado, enquanto que, por outro lado, as condições de inscrição e de indemnização dos "com-direitos" e de sobrevivência dos já em situação de "termo de direitos" se degradavam sucessivamente (Maurer e Mayer, 2001).

Maurice Pagat cria o sindicato dos desempregados em 1982, ampliado depois no Mouvement national des chômeurs et précaires (MNCP), que tematiza o problema social dos "novos pobres" e conduz à criação do rendimento mínimo de inserção (RMI) em 1989, sob a direcção de Jean-Michel Belorgey. Elementos próximos do PCF fundam, em 1987, a Association pour l'emploi, l'information et la solidarité des chômeurs et des travailleurs précaires (APEIS), a qual denuncia o regime de segurança-desemprego gerado pelo patronato e pelos sindicatos na UNEDIC (União nacional para o emprego na indústria e no comércio). Estas estruturas reagrupam-se na Ligue des droits de l'homme (LDH), em Droit au logement (DAL) e através de sindicalistas não confederados ou não alinhados no seio do Groupe des 10. Uma constelação de colectivos gravita à sua volta, como é o caso de Chôm'Actif ou o Réseau Stop precarité, que emergiu na altura das "hamburgreves" do MacDonald's e das lutas dos trabalhadores da Pizza Hut (Mabrouki e Lebigue, 2004).

Uma vez mais, constata-se a estrutura reticular de pequenas organizações cujos membros tentam federar-se mas nem sempre se entendem, devido à disparidade dos seus objectivos materiais e das suas sensibilidades políticas. Cria-se mesmo uma certa tensão entre tomadas de posição por vezes utópicas - que visam a superação do capitalismo ou a abolição da miséria e iniciativas de colaboração com dispositivos de acção pública que permitem abordar os problemas de modo pragmático.

Os "mal alojados" e os "sem abrigo" (Péchu, 1996) são apoiados pelo Comité des mal logés (CML, 1987-1993), pelo Droit au logement (DAL, 1990) e o Comité des sans-logis (CDSL, 1993). Os sem abrigo são muitas vezes 
imigrantes impedidos de aceder ao mercado de arrendamento por motivos racistas, jovens excluídos do rendimento social de inserção ou famílias monoparentais, caídas na rua por perda de emprego ou por sobreendividamento.

As associações como o DAL preconizam a requisição de imóveis desabitados, com vista a atenuar as insuficiências do parque imobiliário; pedem, além disso, o apuramento das dívidas das famílias de baixos rendimentos, o controle das habitações sociais ou dos lares de jovens trabalhadores que se servem frequentemente de métodos arbitrários; a aplicação da lei Besson de 1990 - que obriga a realojar pessoas expulsas e não simplesmente a dar-lhes guarida; enfim, a melhoria do funcionamento do serviço de emergência médica social e o acesso às habitações de renda social das pessoas sem recursos. Estas associações tomam amiúde a cargo os "trabalhadores precários", batem-se contra as "doenças da miséria”, informam dos seus direitos de protecção social e de cobertura de doença, assegurando-lhes cuidados de saúde gratuitos.

Ao seu lado estão os "sem-documentos" (Siméant, 1998), cujas lutas se impuseram ao público em 1996, com o caso dos africanos ilegais expulsos manu militari da igreja Saint-Ambroise.

A questão dos ilegais foi abordada primeiramente por organizações como o CDSL, Droits devant!! e Médecins du Monde, que se deram conta da presença de numerosos "clandestinos" na rua $d u$ Dragon. Uma boa parte destes "clandestinos" estava em situação regular, pagava os seus impostos e as suas quotizações, mas acabou marginalizada pelos novos regulamentos ou por situações como, por exemplo, um momento de desemprego provisório durante a renovação da licença de residência ou um arrendamento não declarado pelo proprietário e classificado como acto de ocupação ilegal de habitação. Eles são arregimentados em "zonas de não direito", que consistem em "centros de detenção" (Laacher, 2002) e, se forem condenados a expulsão, reconduzem-nos à fronteira pela força.

À lei Paqua-Debré sucedeu a lei Chevènement, que suscitou uma mobilização igualmente forte. As reivindicações mantiveram-se: o acesso a todos os direitos e a regularização de todos os ilegais; o fim das expulsões degradantes em "charter"; a anulação das perseguições às associações de apoio "não acreditadas" pelo Estado; a liberdade de circular e de se fixar no país escolhido; por último, a supressão da "dupla penalização" que consiste no reenvio para o seu país de origem, de antigos reclusos depois de terem cumprido pena de prisão.

As lutas das "mulheres" recuperaram o seu impulso inicial com a fundação da Coordination des associations pour le droit à l'avortement et à la contraception (CADAC), em Outubro de 1990, devido ao crescimento da 
Frente Nacional e dos ataques de comandos anti-IVG contra hospitais e clínicas. Os seus temas de luta predilectos são o estatuto reservado às mulheres pela ordem moral da extrema-direita, as tentativas de abolir as leis sobre a contracepção e o aborto, a sua não promulgação na Irlanda, na Polónia e em Portugal, as violências sofridas pelas mulheres, as desigualdades e discriminações no trabalho, a não partilha das tarefas domésticas e a dupla jornada de trabalho, a pandemia do HIV e da Sida, enfim, os problemas com que se deparam os casais homossexuais. Paradoxalmente, é declarada guerra contra o "sistema prostitucional", em nome de um "direito à insubmissão sexual". A reivindicação pode ser radical e exigir a erradicação e a penalização de toda e qualquer prática de prostituição, apresentada como uma forma de exploração sexual frequentemente associada à miséria, senão mesmo à escravatura.

Tal reivindicação nem sempre coabita pacificamente com as mobilizações das prostitutas (Mathieu, 2001), que são manifestamente anti-abolicionistas e defendem os seus interesses corporativistas de "trabalhadoras do sexo" exigindo mesmo a sua legalização, e cuja situação ficou fragilizada com as novas leis repressivas de Sarkozy.

\section{Perfis sociológicos e formas organizacionais: rupturas e continuidades}

Este traje de Arlequim não é feito de um tecido só. Atribuir uma unidade aos interesses, às análises e às propostas das diferentes NMP e conceder-lhes um poder concertado para modelarem uma contra-política, poderia originar uma ilusão análoga à dos NMS que, nos anos setenta, eram supostos substituir as organizações do "movimento operário" e impulsionar uma política alternativa. Este sonho é, sem dúvida, ainda acalentado por partidos políticos como a LCR e o PCF, que tentam, de acordo com alguns pontos de vista, "instrumentalizar o movimento social". Mas a sigla NMP agrega colectivos cuja característica é não se fundirem num "sujeito contestatário" unificado.

A coordenação entre estes diferentes "colectivos" é problemática - muito heterogéneos nas suas formas, recursos, organizações, estratégias ou ideais e amiúde demasiado dispersos para constituírem, excepto em objectivos muito focalizados, centros de contra-poder, não tendo muitas vezes outra ambição para além de informar, denunciar e reivindicar, sem pretenderem comprometer-se num esforço de ruptura radical e, em muitos casos, preocupados em conservar a sua autonomia contra qualquer propósito de recuperação política.

Acresce a isto o facto de um certo número de traços merecer um inventário, testemunhando mutações do compromisso público - político, sindi- 
cal, humanitário e associativo em geral. Tentemos seriar alguns dos pontos de semelhança e de distinção destes movimentos emergentes em relação aos seus antepassados materialistas e pós-materialistas...

Em primeiro lugar, as trajectórias de certos líderes, ex-militantes católicos, comunistas ou esquerdistas, mas também ecologistas, feministas ou pacifistas que se tinham retirado, após 1981, para associações de perfil mais técnico ou mais ligadas à gestão. Eles são frequentemente os quadros fundadores e mais experientes dos NMP, tendo reactivado o que restava das suas antigas redes de relações e modificando os seus esquemas de análise para os ajustar às novas situações.

Esta continuidade surgiu nos meios intelectuais durante os acontecimentos de Dezembro de 1995. A lista dos nomes dos signatários das petições, apelidadas "Bourdieu" e "Esprit", funcionava como um instrumento de análise das "duas esquerdas" que se defrontam, em França, há meio século. De um lado, a ex-"segunda esquerda" de Rocard ou de Delors, a direcção da CFDT, intelectuais como Touraine ou Rosanvallon, membros da revista Esprit, do Centre Raymond Aron e da Fondation Saint-Simon, que acusava de corporativismo os movimentos de Dezembro de 1995 (Capdevielle, 2001); do outro lado, uma esquerda mais marxisante, reagrupada em torno do le Monde Diplomatique, da galáxia reconstituída em torno de Bourdieu, próxima das posições da FO e da CGT e reforçada pela vaga de fundo das NMP.

Operfil sociológico dos grupos mobilizados, composto por classes médias bastante escolarizadas, com uma boa proporção de funcionários dos serviços públicos, uma sobrerepresentação dos jovens nos movimentos alter, sem verdadeiro recrutamento nas "categorias populares", lembra ainda o dos NMS - ainda que nos movimentos de desempregados e de trabalhadores ilegais tenham surgido líderes vindos das próprias bases.

As investigações dos politólogos mostraram que as coisas se complexificaram. Nos movimentos de trabalhadores precários como o DAL (Réchu, 2001) ou entre os ecologistas (Ollitrault, 2001), as sínteses nem sempre são fáceis entre gerações de militantes, de acordo com a idade, a data de mobilização e a trajectória de participação, a rede de pertença e o tipo de politização dos problemas. Encontram-se lado a lado diferentes sensibilidades: os sobreviventes dos NMS nem sempre se integram bem com os ex-trotskistas e têm dificuldade em compreender os jovens iniciados na vida pública, após a queda do comunismo e do mitterrandismo.

Outra semelhança apontada pelos observadores: o lugar preponderante do Estado, em França, na organização da vida associativa, da solidariedade social ou da animação cultural e uma cultura cívica propícia a atitudes extremadas, de confrontos abertos e de greves massivas em detrimento do 
lobbying, da negociação e do compromisso. Os NMP têm como área de predilecção o sector público: SNCF e RATP, Air France, hospitais e universidades - tal como há trinta anos, o poder nuclear da EDP, o centralismo jacobino da administração ou o autoritarismo hierárquico da Universidade. Os funcionários e os utentes batem-se contra o desmantelamento dos serviços públicos, a favor dos seus "direitos sociais adquiridos", em nome dos "valores republicanos".

Todavia, a continuidade pode igualmente ser pensada a partir das temáticas. Os conflitos, continuando embora a incidir nas esferas do trabalho e da produção, mostram-se em conformidade com as preocupações pós-industriais: reconhecimento de minorias activas, em particular homossexuais; melhoria do quadro de vida e da qualidade de vida; protecção do ambiente e do património; desenvolvimento das regras de actuação da democracia participativa (Bevoit, 2002).

A utopia, tantas vezes denegrida no decurso dos anos oitenta, está de volta mas liberta do mito dos “amanhãs que cantam” (Bensaïd, 1995), preocupada em preservar direitos humanos e sociais aplicados num futuro imediato, sem no entanto descurarem as gerações futuras. A "sociedade de consumo" está de novo na mira dos contestatários. As críticas ao espírito mercantil, às tecnologias baseadas no domínio da natureza, ao depauperamento crescente dos recursos naturais, às preferências de privatização em matéria de transportes ou aos mercados cativos da produção agro-alimentar ganham terreno. A batalha contra a publicidade e a "tirania das marcas" (Klein, 2001) está no auge, enquanto o comércio ético ou igualitário começa a emergir.

A crítica social estendeu-se, contudo, a novas frentes. A formulação da questão social mudou entretanto de registo. Os direitos sociais eram então considerados como métodos de controlo social e ilusões da ideologia burguesa, que integravam as classes populares na sociedade salarial e de consumo. $\mathrm{O}$ acesso à cidadania social é hoje em dia considerado um bem comum e está no cerne das reivindicações dos NMP.

A privação de certos direitos sociais, erigidos em direitos fundamentais da pessoa - enquanto os direitos do homem e do cidadão eram, outrora, rejeitados sob a acusação de serem formais e abstractos - convertem-se no critério de definição a contrario dos "sem direitos". "Direito à habitação, Direito ao trabalho, à função social, Direito à saúde, aos cuidados médicos, Direitos ao conhecimento, à formação, Direito à cidadania, Direito à justiça, Direito aos tempos livres, às férias, à criação, Direito à liberdade de circulação (Manifesto dos Droits devant!!, Dezembro de 1994)... A sociedade salarial e o Estado social tornaram-se os bens mais desejáveis. 
Existe outra diferença em relação aos anos setenta: a linguagem da luta de classes transformou-se. Os acontecimentos de Dezembro de 1995 criaram a ilusão de uma federação dos "pequenos" contra os "grandes", do "povo" contra as "elites". Mas paralelamente às clivagens entre elites neoliberais e assalariadas, as clivagens entre assalariados e excluídos são hoje notórias. Os projectos de aliança entre as categorias dos "dominados" e dos "espoliados" na esfera do mundo salarial e do mundo não salarial não são pacíficos. O monopólio da representação sindical marginaliza os não assalariados e afasta-os dos organismos paritários, impedindo o pleno reconhecimento das organizações de desempregados.

A diferença entre os estatutos da função pública e os contratos no sector privado é um outro motivo de divergência de interesses.

Quanto à superação da oposição entre as populações prósperas do Norte e as populações carenciadas do Terceiro Mundo e do Quarto Mundo, reivindicada por todos os NMP, continua a ser mais uma figura de retórica do que uma realidade.

Novas formas organizacionais coabitam com as antigas: partidos que não renunciaram às suas raízes bolcheviques ou trotskistas, com outros que aliam a retórica anti-capitalista com a abertura aos "movimentos sociais" - estudantes, feministas, anti-racistas, anti-fascistas. A LCR preconiza a "autogestão, o feminismo e a ecologia", encontra-se representada no seio da CFDT e do SUD, estabeleceu relações com as Motivé-e-s - objecto político não identificado que teve o seu primeiro impulso no meio associativo de Toulouse, em torno do grupo musical Zebda, antes de se difundir e de obter alguns bons resultados nas eleições municipais de 2001 e nas legislativas de 2002. Por seu lado, redes ecologistas e anarquistas actuam a par de organizações estudantis ou profissionais.

Além disso, novos sindicatos estão a constituir-se. SUD-PTT (Solidaires, Unitaires, Démocratiques) teve a sua origem no movimento dos funcionários dos correios de 1988 (Sainsaulieu, 1999). Beneficiou da sangria de militantes de uma CFDT recentrada em torno da regulação dos mercados e dos processos de negociação, criticada pela sua ala esquerda devido às suas tomadas de posição "social-liberais", designadamente quanto ao sistema de aposentações. Nesse sentido, demarcou-se do pesado aparelho da CGT, adoptando uma forte autonomia dos sindicatos departamentais, a limitação da duração dos mandatos, a representação por um terço de mulheres e outro terço de membros da província no Comité Federal.

O SUD-PTT rapidamente se difundiu, atraindo a si assalariados, sobretudo nos serviços públicos, seduzidos por um estilo de acção que se demarca 
claramente das grandes confederações pelo seu tom libertário, sem por isso perder a sua credibilidade técnica e organizacional.

A Confédération paysanne (CP), dirigida por José Bové e François Dufour, luta "por uma agricultura camponesa e duradoura num mundo solidário". Ela batalha no terreno da FNSEA, o sindicato maioritário no sector agrícola, que desde os anos sessenta ocupava um lugar indestronável como parceiro corporativista do Ministério da Agricultura. A CP defende os interesses bastante sensíveis dos agricultores, mas ela joga igualmente com um trunfo militante muito forte noutras frentes de luta. Ela deplora o abandono de espécies tradicionais de cereais, do arroz ou da soja (respeito pela biodiversidade); afirma o direito dos povos à soberania alimentar e denuncia a confiscação do seu património genético (luta a favor do Terceiro Mundo); reclama moratórias para a investigação privada e pública (programas BioAvenir de Rhône Poulenc ou Génoplante); denuncia o monopólio dos serviços e da propriedade dos recursos naturais por parte das multinacionais da agro-indústria; critica a situação de dependência técnica e económica das economias camponesas. Ela alinha, enfim, com os temas do alter-mundialismo, ao criticar as políticas da política agrícola comum (PAC), do Banco Mundial (BM) e do Fundo Monetário Internacional (FMI), da Organização Mundial do Comércio (OMC) e da Organização para a Cooperação e o Desenvolvimento Económico (OCDE), requerendo simultaneamente a suspensão do uso de organismos geneticamente modificados (princípio de precaução) e exigindo o direito a uma alimentação saudável acessível a todos ("contra a comida de plástico") - acções que contribuem para o seu sucesso público.

A distinção entre as categorias das associações, dos sindicatos e dos partidos é cada vez mais problemática. Ao que parece, os seus tipos de organização, os seus projectos de sociedade, instrumentos de análise e modos de acção deixaram de ser incompatíveis. A forma da "coordenação" (Denis, 1996) impôs-se nos anos oitenta, na altura das greves estudantis de 1986 contra a lei Devaquet, tendo sido retomada pelos ferroviários do SNCF, pelos professores primários, pelos Snecma-Air France e pelas enfermeiras. Ela acompanha o recuperar das temáticas da "democracia participativa e deliberativa", que é uma resposta simultaneamente ao mau funcionamento das agências administrativas e das colectividades públicas em matéria de inovação social, e ao desejo de participação crescente de uma franja de cidadãos, desconfiados face aos eleitos e aos especialistas.

As organizações convertem-se, elas próprias, numa espécie de arenas públicas e de redes de activistas, as quais participam em fóruns de discussão (Mouchard, 2002), coligam-se noutros campos de luta e incorporam uma 
série de compromissos individuais (Szczepanski, 2002). A forma em "rede" é a mais expandida, com os seus fracos constrangimentos em matéria de hierarquia, de centralização e de institucionalização. Ela põe em conexão organizações de toda a espécie e de qualquer dimensão. Daí, derivam estratégias compósitas, em que as decisões devem incluir os diversos actores, encontrando-se uns e os outros nas manifestações, nas ocupações ou nos fóruns electrónicos, sem que por isso renunciem à sua autonomia. A modificação das formas de compromisso público ocorreu paralelamente ao desmoronamento das "constelações de pertença" ideológica, religiosa ou política (Ion, 1997).

É um mundo barroco que se desenha, com múltiplos estados-maiores, sem a unidade de um quadro organizacional, sem imperativos de centralismo democrático, sem submissão a uma ideologia comum. Uma boa parte destes actores partilha uma preferência pela participação directa, podendo contudo seguir igualmente os canais da representação e do lobbying ${ }^{2}$ políticos. Ao insurgirem-se contra a Europa económica e tecnocrática, eles podem, contudo, levar uma dada causa aos tribunais internacionais, como por exemplo, o Tribunal Europeu dos Direitos do Homem. Eles podem criticar as organizações inter-governamentais e dirigir-se à Organização Internacional do Trabalho. Eles afirmam a sua desconfiança relativamente ao direito, recorrendo contudo a ele livremente; alimentam muito poucas ilusões sobre a representação política e, no entanto, votam, e para uma fracção da ATTAC, acalentam o sonho de formar listas eleitorais.

As ligações entre todos estes "movimentos" são asseguradas pelas suas participações cruzadas nas manifestações, nas análises e nas acções de uns e de outros. Por um lado, os seus membros circulam de um colectivo para outro - sem que se possa já falar no sentido forte do termo "multi-aderentes", dado que os compromissos já não são necessariamente selados por via de um cartão ou de quotização. Por outro lado, os colectivos não estão fechados sobre si mesmos de maneira exclusiva, como acontecia com os grupúsculos esquerdistas - as "estruturas inter-associativas" proliferam. Cada associação reparte-se em redes de ligações com outras associações. Estas múltiplas estruturas formam-se e desaparecem, caem num certo torpor ou são reactivadas ad hoc, não sendo animadas em continuidade senão por algumas raras pessoas - viveiros de activistas que militam "à la carte", comprometem-se e descomprometem-se segundo as contingências da sua vida familiar e profissional, que se envolvem num determinado dispositivo e que se retiram ao mínimo desentendimento.

\footnotetext{
${ }^{2}$ Em inglês no original (N.T.).
} 


\section{Mobilizações inéditas: a invenção de novos repertórios de acção}

As manifestações são sempre métodos de expressão pública de primeiro plano. Porém, contra os desfiles sérios e a passo lento, novas tácticas foram aplicadas. As manifestações tornaram-se espaços onde se canta e dança: canções em voga são adaptadas com letras militantes, as canções de Zebda são recuperadas colectivamente, grupos de percussão marcam o passo ao ritmo do samba, e a monotonia da marcha é quebrada por arranques repentinos.

As manifestações converteram-se também em ocasiões lúdicas de disfarces, de paródia teatral ou de transgressão carnavalesca: emblemática, a Gay Pride tornou-se um acontecimento tão incontornável como as manifestações do primeiro de Maio. Toda a manifestação que se preze deve ser colorida e atraente - a menos que, por contraste, adopte a estratégia do tudo-de-branco ou do tudo-em-silêncio, como aconteceu na Bélgica, nas manisfestações que ocorreram na altura do caso Dutroux. A presença de personalidades mediáticas tornou-se o garante de repercussão de um determinado acontecimento. Jacques Higelin em relação ao DAL, Emmanuelle Béart em Saint-Bernard, Albert Jacquart e Léon Schwartzenberg em todos os desfiles, Monsenhor Gaillot representando a facção mais progressista da Igreja, Abbé Pierre, o favorito dos franceses nas sondagens, figura tutelar dos movimentos caritativos em França, Coluche, ícone humanitário...

Por outro lado, se os slogans da $A C !$, da Act Up ou do DAL têm um cunho pré-fabricado e se novas palavras de ordem anti-mundialização emergiram em substituição dos velhos refrões de extrema-esquerda, há cada vez mais lugar para a expressão de testemunhos. A militância personalizou-se.

As manifestações de Dezembro de 1995 eram um patchwork de agrupamentos e de indivíduos com motivações muito heterogéneas que, num ambiente eufórico de quermesse popular, tinham prazer em representar de novo os tempos da esquerda popular - jogando com as máscaras do Eu. A emoção pessoal lia-se nos cartazes e bandeiras improvisados para a manifestação contra Le Pen nas eleições presidenciais de 2001, em que os slogans tinham dado lugar a mensagens de cunho pessoal. O sentimento de crise e de angústia disfarça-se com atitudes provocatórias e imaginativas: revela o seu profundo enraizamento na experiência dos indivíduos.

Outros repertórios de acção emergiram. As "marchas" estão vocacionadas para publicitar e popularizar uma dada luta, criar fóruns de discussão nas cidades por onde passam e sensibilizar, mobilizar e recrutar novos membros. A primeira foi a Marcha dos beurs, em 1983, pela igualdade e contra o racismo, com os seus slogans característicos: "Não toquem no meu amigo"; "A França é como uma motocicleta, precisa de mistura 
para andar". A marcha da $A C !$, em 1993-94, foi ultrapassada pelo seu próprio sucesso. Lançada por sindicalistas e grupos de associados, ela agregou aos seus desfiles, vindos de cinco cidades, uma massa de 30.000 pessoas contra o desemprego e a miséria, tendo-se prolongado pelas Marchas europeias contra o desemprego. Em 2002, Ni Putes ni soumises, um grupo de jovens mulheres e homens apoiado pelo colectivo La Maison des Potes, fez uma "volta a França republicana", em Março de 2001. Em cada uma das cidades da etapa, fóruns de discussão abordaram problemas como as formas de violência sexista, os bandos organizados, os casamentos forçados e os integrismos religiosos. Comissões femininas de bairro eram criadas para acolher "mulheres caídas em desgraça" e informá-las dos seus direitos. A reivindicação consiste na criação de um "espaço público misto e unificado", articulado pelos valores da liberdade, da igualdade e do respeito. Mas, a publicidade recebida pela marcha permitiu a criação de uma comissão interministerial, a abertura de lugares experimentais - os "espaços mulheres", lugares de ajuda e de reconforto -, a organização de seminários de formação para as monitoras e o desenvolvimento de espaços de acolhimento de raparigas e mulheres vítimas de violência, nas instalações dos comissariados da polícia. Deste modo, as marchas não constituem um fim em si mesmas, sendo antes fantásticos vectores de publicidade, operadores de encontros, incubadoras de projectos, fóruns de expressão e de discussão públicas.

As "ocupações" impuseram-se entre os diversos repertórios de acção. Uma das mais regulares tem sido, desde 1988, a das antenas locais das ASSEDIC (Seguro desemprego) que é levada a cabo pelos desempregados em cólera, com uma longa luta em Dezembro de 1997 que suscitou um forte movimento de solidariedade, quando os apoios financeiros de emergência e os subsídios de Natal foram suspensos.

As reivindicações continuam a ser a concessão de iguais direitos aos desempregados e aos trabalhadores assalariados, a reforma dos fundos sociais de apoio, o reconhecimento da representação das organizações dos desempregados nos organismos paritários, a colocação dos rendimentos sociais de inserção ao nível do salário mínimo e, enfim, a supressão da contínua degradação das condições de vida dos desempregados.

Em resultado da pressão exercida pelos AC, APEIS, MNCP, CDSL e CGT Chômeurs, o Primeiro-Ministro recebe pela primeira vez associações de desempregados. Por seu lado, ocorrem ocupações e também "requisições" de edifícios desafectados pelo DAL - de entre as quais a mais célebre foi a do edifício vazio da COGEDIM, na rua du Dragon, a 18 de Dezembro de 1994 - tendo como resultado o realojamento de todos os seus "ocupan- 
tes" antes de Janeiro de 1996. Este local converteu-se numa "casa da solidariedade" na qual participavam organizações como a DAL, CDSL, AC! e APEIS, dando lugar a iniciativas experimentais como uma Universidade popular e um Observatório internacional das prisões e tendo ainda alojado a fundação Droits devant!!

Como consequência, as ocupações multiplicaram-se: locais Assedic, estações ferroviárias, hotéis, ministérios. Tais ocupações permitiram a regularização de centenas de imigrantes ilegais, o acesso ao trabalho de centenas de desempregados e à habitação de centenas de sem-abrigo.

Pelo contrário, certos repertórios que se mostraram eficazes na Alemanha ou nos Estados Unidos não são seguidos em França. O "boycott" deu provas no exterior, e a campanha do Greenpeace, em 1995, contra a plataforma petrolífera da Shell no mar do Norte, levou a empresa a recuar. Outras campanhas, com resultados menos espectaculares mas igualmente publicitadas, incidiram sobre a exploração do trabalho infantil nos países do Sul pela GAP, Nike e Levis. Em França, o boicote da Danone pela ATTAC não teve senão um débil impacto sobre as vendas. As empresas contrapõem com as "ética business", "mundialização responsável" e "acção afirmativa", "desenvolvimento sustentável" e "comércio ecológico"...

Enfim, estes diferentes movimentos lançam "Apelos": o Apelo dos "sans", de Dezembro de 1995; o Apelo do Louvre, elaborado durante a ocupação do Carrousel e assinado a 20 de Dezembro de 1997 pelas organizações do movimento dos desempregados (AC!, APEIS, CDSL, DAL, DD!!, MNCP, SUD); o Apelo dos movimentos sociais europeus, lançado a 10 de Novembro de 2002, na sequência do Fórum Social Europeu de Florença, em "guerra" contra a guerra, o neo-liberalismo, o racismo e o patriarcado, o sexismo e a homofobia...

\section{A explosão dos militantismos informacionais: públicos sociotécnicos}

A análise dos repertórios de acção e de organização não é suficiente para dar conta das dinâmicas da acção colectiva. Os NMP desenvolvem igualmente culturas de protesto: eles articulam contextos de experiência, campos de memória e horizontes de expectativa onde se inserem trajectórias de vida individuais e colectivas. Estão subordinados a retóricas e a dramaturgias da indignação e da justiça, da igualdade e da solidariedade, do direito e da responsabilidade que os tornam pertinentes. Elas radicam em projectos de solidariedade e interpretações da história, promovem concepções da relação entre Estado e sociedade e gramáticas da boa convivência.

\footnotetext{
${ }^{3}$ Em inglês no original (N.T.).
} 
Os lugares da Internet são os sítios privilegiados destes cadinhos de cultura. De modo geral, a ciência e a técnica entraram em força na política. A crítica à vaga tecnocrática já não colhe. A palavra de ordem é, aliás, a "democracia técnica", em "fóruns híbridos" onde especialistas e leigos se confrontam com dispositivos sociotécnicos (Callon, Lascoumes e Barthe, 2001).

Paralelamente, a crítica aos media transformou-se. O "mediactivismo" apercebeu-se do partido que pode tirar do ciberespaço: custos mínimos, uma maior simetria entre produtores e consumidores de informação, uma ubiquidade imediata das mensagens sem qualquer dilação no tempo, um formidável instrumento de comunicação e de coordenação entre activistas.

Sem um tal medium, que veio substituir com vantagens o telégrafo e o telefone, depois, em 1986, nas organizações estudantis, a telecópia por fax e, por fim, o telemóvel, usado com habilidade pelos imigrantes ilegais de St. Bernard, em 1996 - as mobilizações do Fórum Social Mundial, contra Davos ou o G8, seriam literalmente impensáveis.

Dominique Cardon e Fabien Granjon distinguem os "media estratégicos" - os quais se esforçam por controlar, criticar, corrigir e reformar os media institucionais - dos "media tácticos" (Cardon e Granjon, 2003). Os primeiros actuam no terreno da objectividade crítica no espaço público. Eles realizam um trabalho de contra-peritagem reportado a um ideal de objectividade: criticam a dependência face aos comanditários, o unilateralismo das fontes de informação, a deformação das informações e recorrem a um longo período de investigação e reflexão no trabalho de produção da informação.

Além disso, apontam toda a espécie de distorções: a desigualdade de tempos de antena, a destruição do diálogo pelos ritmos das emissões, a exclusão de determinados grupos do tempo de antena e o monopólio das declarações públicas por parte de elites coniventes; a indexação da qualidade dos programas à sua rentabilidade nas estatísticas de audiência e a ditadura das agências de publicidade sobre as escolhas da programação; a mercantilização dos bens culturais que se traduz pelas práticas de infotainment ${ }^{4}$, a desmultiplicação de jogos ou de reality shows ${ }^{5}$, a escalada de vulgaridade e de sensacionalismo, de pornografia soft, de exibicionismo da intimidade e do culto do herói.

Os media estratégicos continuam a ter uma vocação emancipadora.

Em contraponto a estes "media estratégicos", desenvolve-se a frente dos "media tácticos", que tentam elaborar novos formatos de crítica social. Eles querem libertar uma criatividade colectiva na qual, em contraponto

\footnotetext{
${ }^{4}$ Em inglês no original (N.T.).

${ }^{5}$ Em inglês no original (N.T.).
} 
aos monopólios sob a alçada dos media estatais e privados, se faça ouvir uma voz colectiva. Diversos servidores sem interesses comerciais, "independentes e autogeridos" - Domaine public, Independant Networg, GlobeNet ou l'Autre Net - acolhem projectos alternativos, associações sem fins lucrativos, várias ONGs e colectivos de activistas. Eles próprios assumem a estrutura de associações sem fins lucrativos, fornecem apoio logístico ao terceiro sector e colaboram no desenvolvimento de aplicações web. Para alguns, eles visam uma apropriação "mútua" e "solidária" dos utensílios da net, criticando os monopólios da especialização electrónica, em particular da Microsoft.

Está instalada a guerra contra as multinacionais a partir da frente do "hacktivismo". Em certas plataformas, os hackers lutam a favor dos programas informáticos gratuitos. O Copyleft é a antítese do Copyright. Ele coloca programas informáticos no domínio público mas advoga a favor de uma inteligência cooperativa: os programadores que contribuem para melhorar programas livres (Stallman) não lucram economicamente com isso, trabalhando, no entanto, colectivamente para aperfeiçoar um bem comum, pertença do domínio público. Defendem, assim, programas informáticos evolutivos, nos quais se estabelecem redes de trocas de saberes técnico-científicos, à maneira dos públicos de Dewey, contra a exploração comercial de licenças que privam os utilizadores de qualquer controlo sobre os seus utensílios.

Deste modo, o programa informático livre estende-se às obras de arte na web.

Outros batem-se igualmente pelo respeito das liberdades privadas por parte dos fornecedores de acesso e pela confidencialidade das trocas, contra o ciber-controlo. Lugares de informação como Téléweb, NoBabylon, Samizdat e Indymedia, Agitkomou, o CMAQ (Centre des médias alternatifs du Québec) estão em rede, do mesmo modo que media livres, tais como Zalea TV, CPML e Tiers Secteur AV.

As televisões alternativas lutam contra o pensamento único, a uniformidade e a insignificância. As suas reivindicações consistem na "criação de um fundo de apoio" financiado por uma taxa sobre os lucros das empresas audiovisuais e operadores de rádio; a "obrigação de transporte gratuito" dos canais associativos pelos operadores comerciais de difusão hertziana, por cabo e satélite; o "atenuamento da responsabilidade legal dos difusores" associativos para os programas fornecidos por particulares, devendo cada um ser considerado responsável pelas suas propostas; enfim, a criação pelo Conselho Superior do lAudiovisual (CSA) de um caderno de encargos específicos para os canais que se reclamam dos "valores da economia solidária". 
Estas televisões alternativas, que tinham obtido a sua legalização em 2000 com o governo de Jospin, hoje em dia são objecto de interdição de difusão hertziana pelo CSA. Elas coabitam com colectivos independentes de artistas e produtores, como a Video Activism Network ou o Regarde à Vue. Ao mesmo tempo que a Copyleft Attitude tenta uma transferência das práticas dos programas informáticos gratuitos para as obras de arte, suprimindo a noção de autor proprietário da sua obra e a redução da obra a mercadoria, a Republicart, por seu lado, promove a crítica artística. Outras páginas electrónicas, como as Oxalis, Synesthésie e Teleportacia, expõem arte numérica. São objectos gráficos e plásticos submetidos a práticas de mistura e remistura diversas, performances, documentários-ficção e filmes alternativos.

Um "terceiro-sector audiovisual" (Allard, 2003) estaria actualmente a emergir. Um Fórum europeu dos media alternativos teve lugar em Paris, em 2003, na Maison des Métallos, com a finalidade de comparar experiências em matéria de técnicas de criação e de difusão. A NewGlobal Vision $(\mathrm{NGV})$ tenta tornar operacionais redes de canais vídeo independentes, bem como tornar acessíveis a todos servidores e bases de dados (Bureand e Manan, 2003). Por exemplo, a tradição autónoma reencontrou o seu prestígio com o sucesso de Negri e de Hardt, o qual fez despertar depois perspectivas situacionistas, anarquistas e de decisão colectiva. Na revista Multitudes, trata-se da "resistência das singularidades livres das multidões contra os dispositivos biopolíticos do Império" (Negri e Hardt, 2000; Virno, 2001; Multitudes, 2002). Para além disso, o ciberfeminismo está em franca progressão, com páginas electrónicas tais como Cybersolidaires e Cyberrebelles, les Guerilla Girls, as Pénélopes ou as Amazones, Internéttes e Sisyphe; estas batem-se tanto pela participação das mulheres nas artes electrónicas e nas tecnologias virtuais, como pela criação de "espaços livres" na net.

Porém, o debate que ocupou o espaço público durante os anos noventa foi o da paridade (Bereni e Lepinard, 2004), tendo culminado na inscrição deste princípio na Constituição. As fronteiras entre o público e o privado foram postas em causa. O desenvolvimento dos blogues, páginas electrónicas onde internautas redigem quotidianamente os seus diários íntimos, compõem listas de ligações comentadas e comunicam entre si em "rede inter-blogues" (Blogtree), criou um novo género de discurso público sobre si e de exibição pública de si.

\section{Não-violência, retórica dos direitos e desobediência cívica}

Jogos na fronteira da legalidade, encenação da moralidade. As estratégias adoptadas pelos NMP combinam um espírito radical, por vezes extremista, com propósitos frequentemente moderados e pragmáticos. Eles 
podem ser perseguidos por desejos utópicos, a realizar incondicionalmente aqui e agora, sem que por isso acreditem verdadeiramente em si próprios ou se levem realmente a sério. O lado lúdico sobrepõe-se muitas vezes ao sonho dos amanhãs que cantam, as preocupações de eficácia organizacional e estratégica disputam a valorização da experiência e da experimentação, a convicção quanto à necessidade da união é contrariada pela débil simpatia pela recuperação e o crescendo de autoritarismo militarista, a transgressão da legalidade, com um certo perfume anarquizante, coabita com a reivindicação de direitos que é necessário fazer reconhecer e validar por leis que protejam os mais fracos contra os abusos do poder.

Os NMP agem por vezes no limite da legalidade ou mergulham literalmente na ilegalidade. Os membros da Confédération paysanne arrancam plantações de arroz transgénico do CIRAD e "desactivam" um restaurante de fast food McDonald em Millau, erguem barricadas e confrontam-se com as forças da ordem. As coordenações de camionistas e os sindicatos de ferroviários paralisam a França em 1995, ao bloquearem todas as vias de comunicação por estrada ou caminhos-de-ferro. Porém, o recurso à violência é muito raro, a não ser sob forma estratégica. A encenação da cólera significa a determinação da luta pelo respeito, a dignidade ou a esperança. O recurso à violência é, nesse sentido, limitado e calculado (Siméant, 1993).

ACT UP desenvolveu os "zaps" (Patonillard, 1998), encenações espectaculares e muito rápidas, focalizadas num problema preciso, forçando os media a cobrir o acontecimento e as testemunhas a reagirem ao vivo. Os jogos que se situam na fronteira da legalidade nunca vão até às agressões físicas a pessoas, mas eles implicam por vezes depredação de bens e prejuízos financeiros. Os excessos de certos grupos anarquizantes - entre os quais os Black Blocks, em Génova - são quase unanimemente condenados, excepto entre os meios da tendência autónoma.

Pelo contrário, existem tácticas alternativas, tais como as dos Tute Bianche e dos Ya Basta!, que consistem em criar grupos-tampão protegidos por tecidos acolchoados e escudos, máscaras e capacetes; fardados de branco, que derrubam as forças de segurança e investem pelas zonas interditadas.

O laboratório dos "desobedientes" substituiu-se a este movimento, que aprendeu bastante com o know how norte-americano - o do Direct Action Network, por exemplo, e dos seus affinity groups, onde activistas que se conhecem dão-se apoio mútuo, assumem responsabilidades, protegem-se e socorrem-se mutuamente nas manifestações. $A C$ ! ou $A C T$ UP unem-se na formação para a acção directa não violenta (Jordan, 2002). 
Sit-ins e die-ins, pickettings e zappings, ${ }^{6}$ distribuições de panfletos e acções em tribunal, marchas e bloqueios, desvios e transgressões simbólicos são "formas activas de resistência" (Manual do ACT UP: Civil Disobedience Training). O objectivo não é provocar a confrontação física mas mostrar o carácter imoral de uma lei, chamar a atenção dos media, comover, chocar e indignar o público.

A referência ao "radicalismo auto-limitado" (self-limiting radicalism) dos movimentos dos países de Leste, retomada a propósito das "políticas da sociedade civil", aplica-se bem aos movimentos dos "sem" (Mouchard, 2002b). O Estado já não é o inimigo a abater nem a fortaleza a conquistar mas, simultaneamente, um adversário contra o qual é preciso lutar e com o qual se deve transigir, a quem se apresenta reivindicações e de quem é preciso obter recursos.

Quer se trate de habitações sociais, de documentos de naturalização, de subsídio de desemprego, de condições para a prática do aborto ou de cuidados de saúde, é o Estado - ou cada vez mais os tribunais da União Europeia - o principal destinatário das exigências de legislação, de medidas, de decisões, de bens ou de serviços, com toda a espécie de ambiguidades, incessantemente relançadas pelas vitórias e derrotas. O rendimento social de inserção pôde ser avaliado como um progresso social, logo depois criticado enquanto dispositivo de controlo dos desempregados "em situação de termo de direitos" e, logo, pelo jogo das condições impostas, como uma via aberta de abandono do welfare $^{7}$ e do endosso do workfare ${ }^{8}$ - do rendimento de inserção social (RMI) ao rendimento mínimo de actividade (RMA).

Cada conquista surge com uma dupla face: a do direito que é reconhecido, conquistado ou concedido, desenhando os contornos de uma cidadania mínima; e, por outro lado, a do poder disciplinar que se intensifica e oprime cada vez mais os indivíduos vulneráveis. A interacção com os poderes executivo, legislativo, judicial e administrativo circunscreve as arenas públicas da denúncia e da reivindicação, da controvérsia e da confrontação. O Estado distribui ou não prestações em bens ou serviços, reconhece ou não os direitos à livre circulação ou ao voto, protege ou não grupos de populações carenciadas.

Os movimentos dos "sem" funcionam num duplo registo: o da reivindicação universal de alcance radical, associada por vezes a um projecto político; e o do posicionamento em relação às agências da ASSEDIC e da ANPE

\footnotetext{
6 Em inglês no original (N.T.).

Em inglês no original (N.T.).

${ }^{8}$ Em inglês no original (N.T.).
} 
(Agência nacional para o emprego), aos gabinetes HLM (Habitação de renda moderada) e ao Ministério dos Assuntos Sociais, às caixas de abonos de família ou à UNEDIC.

No tocante a muitos destes pontos, estamos perante práticas de desobediência civil que aliam a transgressão do direito positivo à reivindicação de novos direitos (Thoreau, 1849). A recusa da ordem jurídica tal como existe combina-se com o apelo a um poder normativo de nível superior direito natural, direitos do homem e do cidadão (Arendt, 1972; Walzer, 1970; Rawls, 1991).

A desobediência civil, ou antes, a "desobediência cívica" tornou-se um tema central, por exemplo, aquando da iniciativa colectiva e pública de recusa da lei Debré sobre a declaração de permanência dos estrangeiros pelo Manifesto dos 121, lançada por um colectivo de cineastas no tribunal de Bobigny. Se uma lei é injusta, as pessoas têm o direito de se revoltar, de lhe resistir e de a rejeitar. Numa situação de urgência (Balibar, 1997), que pede uma resposta imediata, é legítimo ir contra a legalidade. Esta decisão releva da "consciência individual" mas tem um sentido cívico: ela dirige-se a um público, apoia-se num direito acima do direito, requer uma aquiescência de senso comum, apela à responsabilidade colectiva dos cidadãos contra o inaceitável.

Ao mesmo tempo, e paradoxalmente, a dinâmica dos NMP inscreve-se antes de mais na ordem legal e participa naquilo que se qualifica como "juridicização" e "judiciarização" da política (Commaille et al., 2000). Para alguns, ela é acompanhada de uma sobrecarga crescente de reivindicações da sociedade civil, uma "vitimização" dos actores ou dos beneficiários das reivindicações, reconfortada pelos sociólogos que procedem ao recenseamento da "miséria do mundo".

A sociedade civil torna-se o terreno de cenários catastróficos para os condenados da terra e os deserdados do capitalismo, junto dos quais actuam os activistas. A dramatização da indignação perante o sofrimento, a retórica da recusa da miséria do mundo tomaram a forma de uma reivindicação ética que suprime os compromissos políticos. A gramática do humanitário contamina a política de acção colectiva. A "insurreição da bondade" assume por vezes contornos extremistas requerendo medidas imediatas, curto-circuitando todas as mediações institucionais. Ela coloca o público numa postura de compaixão (Boltanski, 1993) e inventa uma nova "martirologia".

Para outros, trata-se de agir no terreno do direito e não nos da compaixão ou da caridade. As pessoas em causa não são "pobres" que dirigem lamentos ou súplicas mas "cidadãos" que reivindicam direitos e que reclamam prestações que lhes são devidas (Fassin, 2000). "Nem excluídos, nem assis- 
tidos: somos seis milhões de desempregados e trabalhadores precários". "Um emprego é um direito, um rendimento é uma dívida", "nós não nos lamentamos, nós apresentamos queixa". A AC! publica um Guia dos direitos dos desempregados.

A questão social tornou-se o lugar central das contradições do novo mundo que emerge. Frequentemente, estabelecendo um paralelo com o século XIX, os "excluídos" tomam o lugar dos "proletários" e a sua integração no espaço da cidadania adquire o mesmo alcance universal que a emancipação da classe operária tinha outrora. O reconhecimento dos seus direitos é o meio de dar um passo suplementar na direcção de um mundo melhor.

De certa forma, o que noutros países é qualificado como cause-lawering, está em vias de se concretizar em França - nos domínios da imigração, da habitação, das causas humanitárias, ou do ambiente. Os movimentos de defesa dos direitos do homem estão representados em França, desde há mais de um século, pela LDH (Agrikoliansky, 2002), fundada em 1898, que reunia cerca de 180.000 aderentes em 1933 e 7000 actualmente, para 330 secções locais no total. Um certo número de pioneiros tinha-se voltado para este domínio desde os anos setenta, como é o caso dos membros do GISTI (Israel, 2003) que desenvolveram na altura um trabalho de informação, de reflexão e de aconselhamento em torno dos direitos dos imigrantes. O DAL, que defende na sua Carta o "direito constitucional e fundamental" (Chauvrière e Duriez, 1995) à habitação para todos, apoia-se numa referência ao direito natural, e retirou do esquecimento a ordenação de 11 de Outubro de 1945 sobre a requisição de casas vazias e o Código da Construção e da Habitação, que dá aos presidentes de câmara e aos prefeitos poder de requisição "em caso de urgência e a título excepcional".

Os Médicos sem fronteiras (MSF) estão na origem da formação de um sector para as questões humanitárias (Dauvin, Siméant e Chier, 2002; Collovald, 2002), e defende o direito de ingerência dos Estados e das ONGs internacionais. Em matéria de ambiente, o princípio de precaução e de responsabilidade é cada vez mais frequentemente colocado em destaque pelas associações ecologistas e de agricultores. As associações e as ONGs investem na função legislativa, na interpretação jurídica e na acção judicial - o que implica, evidentemente, uma dinâmica de profissionalização dos militantes e de tecnicismo das causas mas, acima de tudo, uma transformação das práticas cívicas e dos contextos da acção colectiva. As arenas públicas não são apenas articuladas por gramáticas morais e políticas mas também por gramáticas jurídicas que encontram traduções cívicas.

\footnotetext{
${ }^{9}$ Em inglês no original (N.T.).
} 


\section{Comprometimentos pessoais e experiências de interacção: ser cidadão em situação}

O comprometimento público mudou de regime. Quer se tomem em linha de conta as figuras do agitador, do "desobediente" (Pedretti, 2001) ou do "hacker" (Auray, 1997; Granjon, 2001), quer se observem à lista as transformações da "militância", é-se sempre confrontado com modos de comprometimento que já não significam renúncia de si próprio mas que são acompanhados por uma forte implicação da experiência pessoal (Thévenot, 1999). Este movimento não é novo. Na geração dos anos setenta, o projecto de realização de ideais cívicos ou políticos coabitava já - para os hippies comunitaristas e os regionalistas provençais, os ecologistas antimilitaristas no planalto do Larzac, os Gazolines do FHAR e os Gonines vermelhos - com escolhas existenciais fortes. $\mathrm{O}$ desejo de mais liberdade, igualdade e justiça manifestava-se em mutações radicais da vida quotidiana, que apresentavam formas muito variáveis.

Desde os anos setenta, por conseguinte, a política da vida quotidiana diz respeito a opções existenciais - ela impregna a esfera privada das preocupações com o bem comum e público, inscreve no horizonte de sentido da boa convivência as interacções com os que lhe são próximos, os espaços familiares e os objectos quotidianos, contribuindo para a constituição do seu Eu mais íntimo. Tal dimensão continua a existir hoje em dia. Os skinheads, ${ }^{10}$ os músicos rock e hip-hop, os militantes anti-racistas e anti-fascistas, os anti-publicidade, os libertários e as feministas fizeram emergir nichos de contra-cultura com os seus estilos de vida, as suas fontes de prazer, modalidades de coexistência, vibrações afectivas e perspectivas utópicas e também com os seus representantes e tradutores, os seus inventores, as suas instituições e audiências, os seus mercados e clientelas. Pouco a pouco, foram-se propagando modos de ser, de estar no mundo e de estar com outrém em contraponto à formação de verdadeiros mundos sociais, mercados culturais e arenas públicas.

O comprometimento público actua na dimensão exploratória e experiencial de cada um, bem como nos seus suportes e equipamentos. Ele implica, por essa via, uma redefinição das interacções entre pessoas, uma requalificação das suas situações e uma reformulação das suas identidades. Nesta perspectiva, a cidadania não é um conjunto de direitos e deveres formuláveis na sua abstracção jurídica ou filosófica, e também não é um conjunto de atributos que seriam próprios de indivíduos claramente delimitados e separados uns dos outros. A cidadania consiste, antes de mais,

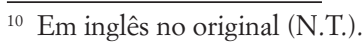


em situações vividas como ocasiões de concretizar bens públicos ou de garantir serviços públicos, encontros em que a liberdade, a dignidade, a igualdade, a justiça ou a solidariedade são realmente experienciadas em acto e nas quais os protagonistas se reconhecem uns aos outros como portadores de direitos e de deveres.

A atenção do investigador deve, portanto, incidir na abertura de novas arenas de tematização dos problemas públicos, na configuração de identidades colectivas e de relações de força com outros actores, na justificação de interesses e de opiniões até então não reconhecidos e na transformação das leis e instituições. Porém, ela não deve limitar-se a isso. Deve também, mediante análises etnográficas, observar as interacções quotidianas dos activistas como os beneficiários das lutas, chamados a serem igualmente actores no terreno da sua vida quotidiana. Por exemplo, as batalhas em torno da aplicação da lei de requisição (de habitações do mercado imobiliário) ou da reivindicação do direito a acompanhamento (às agências de emprego) não são abstractas, elas têm implicações muito concretas para as pessoas nelas envolvidas.

As ocupações das ANPE, de igrejas ou edifícios são momentos fortes de encontro social, operações de combate sob a forma de desafio e de vingança que deixam marcas na memória colectiva, reabrem um sentido dos possíveis em pessoas desesperadas, enfim, restabelecem o sentido da dignidade pessoal contra os actos vexatórios do dia-a-dia. A forma dada às causas colectivas nestas situações públicas tem o poder de reconfigurar contextos de experiência pessoal, bem como redes de intersubjectividade e de interobjectividade que a enquadram. Ela desenha horizontes de compreensão do mundo e de intervenção no mundo.

Os Restaurantes do Coração, fundados por iniciativa de Coluche em 1985 (Salmon, 1998), distribuem ajuda alimentar a mais de 2000 centros, centros esses, que são apresentados como "lugares de acolhimento, de encontro e de partilha". O combate contra a miséria é uma luta pelo direito à existência das $10 \%$ de famílias que vivem abaixo do limiar de pobreza (560 euros por mês), em França.

Por um lado, os Restaurantes do Coração organizam campanhas de apoio com vedetas do espectáculo de variedades que, todos os anos desde 1986, reconstituem o grupo Les Enfoirés, fazem uma tournée, gravam um programa na televisão e editam um disco - publicitando para o grande público os projectos da associação e recolhendo uma parte apreciável das suas receitas. Trata-se de uma acção simbólica, apoiada por vedetas da indústria do espectáculo, que cai facilmente no Charity business. ${ }^{11}$ Todavia, os Restaurantes

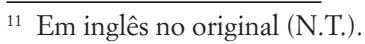


do Coração constituem igualmente lugares onde se desenvolvem relações de presença, em que se cruzam cadeias de cooperação solidária e se concentram tesouros de energia filantrópica. Não se trata de uma simples sopa dos pobres. O envolvimento pessoal não se resume, neste caso, ao envio de um cheque para a conta bancária cujo número passa no ecrã da televisão. A oferta de alimentos é acompanhada de uma troca de atenções e gestos amáveis, do olhar e da escuta, próprios do reconhecimento.

Beneméritos e beneficiários passam pela experiência da solidariedade no terreno, respeitam-se e reconhecem-se uns aos outros como cidadãos de pleno direito - criando condições de decência e dignidade para pessoas que delas estão privadas.

Num outro registo, as associações de luta contra a sida não se limitaram a ter objectivos no domínio da saúde pública e da investigação farmacêutica. ACT UP, por exemplo, luta em numerosas frentes: vigilância face a barómetros de seropositividade que contabilizam o número de pessoas atingidas; lobbying junto dos partidos, das instituições de pesquisa ou das empresas farmacêuticas, das políticas de prevenção ou de educação; acção mais específica a favor das populações prisionais, dos transsexuais ou dos toxicodependentes - programas de distribuição livre de seringas e agulhas ou pedido de distribuição medicamente assistida de estupefacientes; exigência, enfim, de acesso aos cuidados de saúde e terapias diversas nos países mais desfavorecidos.

A relação entre médico e paciente foi sendo pouco a pouco questionada. O poder dos médicos foi abalado pelos casos de infecção, por HIV, em pacientes hemofílicos ou simplesmente sujeitos a transfusões. A sua fraca aptidão para a escuta - particularmente face a certos pacientes incapacitados do uso da palavra e numa total dependência em relação ao corpo clínico - foi vilipendiada.

Em face disto, verificou-se uma aquisição de saberes especializados por parte dos doentes, que aprenderam assim a identificar todos os sintomas de progresso ou degradação da sua saúde, a testar diferentes cocktails de medicamentos ou linhas de tratamento, tendo começado a fazer experiências com o seu próprio corpo e logrando informar-se sobre os programas de fabrico e distribuição de certas moléculas. De pacientes, evoluíram para actores e peritos, "gestores da sua doença" (Barbot, 2001).

Uma verdadeira estratégia de empowerment dos doentes e dos "seropositivos " foi levada a efeito, em nome de uma crítica da xenofobia e da homofobia dominantes. O combate contra a sida é também o de pessoas que reivindicam a sua homosexualidade e se mobilizam enquanto gays (Fillieule e Broqua, 2000) “trans" ou "queers", em vez de se confundirem 
com a paisagem. A formatação de uma causa colectiva tem efeitos de retorno sobre a experiência íntima dos indivíduos.

O mesmo acontece com o movimento dos desempregados. A APEIS aprendeu com a ACT UP a importância da gestão das emoções. Para a ACT UP, "Silêncio = Morte, Acção = Vida". O envolvimento dos desempregados é extremamente problemático, devido ao isolamento, ao sentimento de culpa que experimentam face a si mesmos, ao desprezo com que são tratados pelas instituições (Dethyre, Zeridi-Corniou, 1992), ao desespero e falta de confiança em que o desemprego os faz mergulhar.

As associações que se mobilizaram em favor dos desempregados são duplamente postas à prova. "Quebrar a solidão, reconquistar a confiança, estar informado, entre-ajudar-se e agir, eis o que caracteriza a nossa associação aberta a todas e a todos. Solidária e anti-racista, ela actua prioritariamente com as outras associações de desempregados e com o movimento dos “sem', pela urgência e pela transformação social” (APEIS).

Voltar a ter esperança, reaprender a criar vínculos, a adaptar-se a uma certa disciplina, a respeitar horários, a cooperar com os outros. Encontrar um discurso até aí interdito, por falta de escuta e de representação: os "desempregados" "reconstroem-se" como pessoas, tendo acesso à esfera pública onde a sua "cólera" e a sua "revolta" se podem exprimir, onde podem reencontrar o seu "orgulho" resistindo colectivamente à sociedade de "desemprego massivo", que substitui a do pleno emprego. O conflito com o intuito de ganhar reconhecimento público e de conquistar direitos até então denegados - "fim dos direitos, fome de direitos" - volta a restituir-lhes a sua dignidade de cidadãos de pleno direito, quebrando o círculo do ensimesmamento e da auto-destruição em que a violência, a intolerância, a desconfiança e o desprezo os aprisionam.

Eles reassociam, por fim, as suas trajectórias pessoais a um destino colectivo, podendo da mesma forma dar-lhes sentido e coerência e projectarem-se no futuro, raciocinando em termos políticos e escapando às sirenes da Frente Nacional.

\section{Conclusão}

Desde meados dos anos oitenta, novas arenas públicas foram abertas pelos NMP, seguindo as transformações da sociedade salarial e da política pública, respondendo à mundialização crescente dos mecanismos económicos, estratégicos e sociais. Para quem investe politicamente nos NMP, a importância da sua emergência reside no rearmamento da crítica social e na reconstituição de uma esquerda radical. 
Todavia, estamos no direito de nos sentirmos inquietos com a renovação de um discurso bastante simplista da luta de classes, com o bloqueio de numerosas reformas a coberto da escalada anti-capitalista e anti-liberal ou com o torpedear da constitucionalização das instituições políticas e dos direitos sociais - característica de que era portador o Tratado Constitucional da União Europeia.

Além disso, a formação dessa "esquerda da esquerda" produz conflitos nos partidos de esquerda, em particular os Verdes e o Partido Socialista, que não se entendem sobre as estratégias políticas a adoptar. A sua aliança surge como mal colocada para as próximas eleições presidenciais de 2007, em que parece mais provável a permanência de um presidente da República vindo da UMP (União para um Movimento Popular), presidido por Sarkozy.

O cenário mais dramático seria aquele em que os NMP não mais se contentassem em exercer um "efeito de alavanca" sobre os partidos reformistas, mas decidissem reunir politicamente as suas tropas - ideia que alguns relançaram após a dinâmica do referendo europeu. Porém, constituir uma frente eleitoral entre ambições, sensibilidades e alternativas tão diversas não é a mesma coisa que participar num fórum social mundial...

Acresce que a emergência dos NMP foi crucial na transformação da paisagem social em França, nos últimos vinte anos. Novos problemas públicos se impuseram aos cidadãos, aos especialistas e aos decisores políticos, em particular em torno da questão "sem documentos", dos "sem trabalho" e dos "sem abrigo" mas também da saúde pública, da ecologia ou do consumo. Novos actores colectivos, ONGs, movimentos e coordenações tornaram-se os parceiros e os adversários incontornáveis dos poderes públicos: demarcando-se de uma dominante ideológica, um certo número destes actores colectivos tem uma actuação muito pragmática e envolvem-se em dispositivos de cooperação ou de concertação com líderes eleitos, instituições sociais ou agências administrativas. $\mathrm{Na}$ sociedade civil instalaram-se redes de vigilância e de alerta, de crítica e de intervenção - em torno da sida ou do saturnismo, das ONGs ou do quarto mundo, da poluição ou do alojamento.

Pouco a pouco, e não sem conflito, elas sobrepuseram-se ou substituíram-se aos dispositivos existentes, apoiadas até aí por federações associativas e confederações sindicais. Criaram-se novos equilíbrios entre Estado e sociedade, em torno de questões precisas. Por seu lado, novos espaços de representação, de peritagem e de negociação ganharam legitimidade. Assiste-se a uma pluralização das formas de regime democrático e a uma europeização, senão mesmo globalização das questões públicas (Fillieule et al., 2004). 
Além disso, várias gerações de activistas emergiram, as quais coabitam, nem sempre de forma simples, com a velha guarda do esquerdismo e dos NMS. Foram inventados novos repertórios de acção colectiva, subvertendo as estratégias de publicitação das causas militantes. $\mathrm{Na}$ cena pública, novas personagens se impuseram, fazendo surgir maneiras inovadoras de falar da sociedade e da política, em ruptura com a perpetuação gerontocrática das elites partidárias.

As modalidades de comprometimento público transformaram-se igualmente: a dinâmica que se tinha imposto há trinta anos - do modelo de comprometimento total para o de uma personal politics ${ }^{12}$ (Lichterman, 1996) - confirmou-se. As formas organizacionais já não são as mesmas: a estrutura em redes - flexível, horizontal e policéfala - generalizou-se, facilitada pela mediação técnica da internet. As novas gerações de activistas estão todas "conectadas" e constituem públicos sociotécnicos: a publicidade das causas, dos debates e das lutas desloca-se da rádio e da televisão para as arenas electrónicas. A reivindicação de uma democracia deliberativa e participativa é cada vez mais forte, em oposição ao controlo exercido por aparelhos burocráticos. A "política" não invade a totalidade da vida privada e, ao mesmo tempo, ela não representa um domínio circunscrito, alheado do resto da vida quotidiana. Os inquéritos microsociológicos deveriam ser mais numerosos, a fim de se compreenderem as mutações do comprometimento pessoal e, em contraponto, dos públicos dos NMP.

Tradução de

Maria do Rosário Mariano

\section{Referências Bibliográficas}

Adam, Philippe (1997), Expérience intime et action collective. Sexualité, maladie et lutte contre le sida. Thèse de sociologie. Paris: EHESS.

Agrikoliansky, Eric (2002), La Ligue française des droits de l'bomme et du citoyen depuis 1945. Sociologie d'un engagement civique. Paris: L'Harmattan.

Agrikoliansky, Eric; Fillieule, Olivier; Mayer, Nonna (orgs.) (2005), L'altermondialisme en France. La longue histoire d'une nouvelle cause. Paris: Flammarion.

Agrikoliansky, Eric; Sommier, Isabelle (orgs.) (2005), Radiographie du mouvement altermondialiste: Le second forum social européen, 2003. Paris: La Dispute.

Aguiton, Christophe (2003), Le monde nous appartient. Porto Alegre, Florence, Evian: les acteurs d'une autre mondialisation. Paris: 10/18.

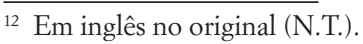


Allard, L. (2003), "Collectifs en ligne et nouvelles arènes publiques. Développer l'audiovisuel numérique libre dans le 'style bazar'”, in Daniel Cefaï; Dominique Pasquier (orgs.), Les sens du public. Paris: PUF, 177-196.

Arendt, Hannah (1972), "La désobéissance civile”, Du mensonge à la violence. Paris: Calmann-Lévy, 55-111.

Auray, Nicolas, "Ironie et solidarité dans un milieu technicisé. Les défis contre les protections dans les collectifs de hackers", Raisons pratiques. Cognition et information en société. Paris: Editions de l'EHESS, 1997, 177-201.

Balibar, Étienne (1997), "État d'urgence démocratique”, Le Monde, 19 février.

Barbot, Janine (2001), "S’engager dans le monde biomédical. Diversité et front commun des associations", in Daniel Cefaï, Danny Trom, Les formes de l'action collective. Paris: Editions de l'EHess, 229-254.

Bensaïd, Daniel (1995), La discordance des temps. Paris: Editions de la Passion.

Bereni, Laure; Lépinard, Eléonore (2004), "Les femmes ne sont pas une catégorie. Les stratégies de légitimation de la parité en France”, Revue française de science politique, 54(1), 71-98.

Bérout, Sophie; Mouriaux, René; Vakaloulis, Michel (1998), Le mouvement social en France. Essai de sociologie politique. Paris: La Dispute, 1998.

Bevort, Antoine (2002), Pour une démocratie participative. Paris: Presses de Sciences Po.

Boltanski, Luc (1993), La souffrance à distance. Morale humanitaire, médias et politique. Paris: Métailié.

Bureaud, Annick; Magnan, Nathalie (orgs.) (2002), Connexions. Art, réseau, média. Paris: Ecole nationale supérieure des Beaux-Arts.

Callon, Michel; Lascoumes, Piere; Barthe, Yannick (2001), Agir dans un monde incertain. Essai sur la démocratie technique. Paris: Seuil.

Capdevielle, Jacques (2001), Modernité du corporatisme. Paris: Presses de Sciences Po.

Cardon, D.; Granjon, Fabien (2003), "Les mobilisations informationnelles dans le mouvement altermondialiste", Comunicação apresentada no colóquio "Les mobilisations altermondialistes", 3-5 décembre.

Cassen, Bernard (2003), Tout a commencé à Porto Alegre. Mille forums sociaux. Paris: Mille et Une Nuits.

Castel, Robert (1995), Les métamorphoses de la question sociale. Une chronique du salariat. Paris: Fayard.

Cefaï, Daniel (2002), “Qu'est-ce qu'une arène publique? Quelques pistes pour une approche pragmatiste”, in Daniel Cefaï; Isaac Joseph (orgs.), L'Héritage du pragmatisme. Conflits d'urbanité et épreuves de civisme. S.1.: La Tour d'Aigues, Éditions de l'Aube, 51-82.

Cefaï, Daniel (2003), "Publics politiques, publics médiatiques”, in Daniel Cefaï; D. Pasquier (orgs.), Les sens du public. Paris: PUF, 8-57. 
Chauvière, Michel; Duriez, Bruno (1995), "Droit au logement contre droit de propriété: les squatters dans la crise du logement”, Annales de la recherche urbaine, 66, 88-95.

Collovald, Annie (org.) (2002), L'Humanitaire ou le management des dévouements. Rennes: Presses Universitaires de Rennes.

Commaille Jacques; Dumoulin, Laurence; Robert, Cécile (orgs.) (2000), La juridicisation du politique. Paris: LGDJ.

Dauvin, Pascal; Siméant, Johanna (2002), Le travail bumanitaire. Les acteurs des ONG, du siège au terrain. Paris: Presses de Sciences Po.

Denis, Jean-Michel (1996), Les coordinations : Recherche déséspérée d'une citoyenneté. Paris: Syllepse.

Dethyre, Richard; Zédiri-Corniou, Malika (1992), La révolte des chômeurs. Paris: Robert Laffont.

Fassin, Didier (2000), "La supplique. Stratégies rhétoriques et constructions identitaires dans les demandes d'aide d'urgence”, Annales HSS, sept.-oct., 5, 953-983.

Fillieule, Olivier; Broqua, Christophe (2000), Les associations de lutte contre le sida. Approche des logiques de l'engagement à Aides et à Act Up. Paris: MIRE, Fondation de France et Crédit coopératif.

Fillieule, Olivier; Blanchard, P.; Agrikolianski, Eric; Balndler, M.; Passy, F.; Sommier, Isabelle (2004), "L'altermondialisme en réseaux. Trajectoires militantes, multipositionnalité et formes de l'engagement: les participants du contre-sommet du G8 d'Evian", Politix, 68, "Militants de l'altermondialisation", 13-48.

Granjon, Fabien (2001), L'Internet militant. Rennes: Apogée.

Hardt, Michael; Negri, Antonio (2000), Empire. Paris: Exils.

Ion, Jacques (1997), La fin des militants. Paris: Editions de l'Atelier.

Israël, Liora (2003), "Faire émerger le droit des étrangers en le contestant, ou l'histoire paradoxale des premières années du GISTI”, Politix, 62.

Jordan, Tim (2002), S'engager. Les nouveaux militants, activistes, agitateurs... Paris: Autrement/Frontières.

Klein, Naomi (2001), No Logo. La tyrannie des marques. Arles: Actes Sud/ Lémea.

Laacher, Smaïn (2002), Sangatte, et après. Pourquoi émigrent-ils? Paris: La Dispute.

Lichterman, Paul (1996), The Search for Political Community: American Activists Reinventing Commitment. New York: Cambridge University Press.

Losson, Christian, Quinio, Paul (2002), Génération Seattle. Les rebelles de la mondialisation. Paris: Grasset.

Mabrouki, Abdel; avec Thomas Lebègue (2004), Génération précaire. Paris: Cherche Midi.

Mathieu, Lilian (2001), "Le mouvement contre la mondialisation libérale”, Regards sur l'actualité, décembre, 17-27.

Mathieu, Lilian (1999), "Les nouvelles formes de la contestation sociale”, Regards sur l'actualité, mai, 33-44. 
Mathieu, Lilian (2001), Mobilisations de prostituées. Paris: Belin.

Maurer, Sophie; Mayer, Nonna (2001), Chômeurs en action, décembre 1997-mars 1998. Mobilisations collectives et ressources compensatoires. Paris: L'Harmattan.

Mouchard, Daniel (2001), Les "exclus" dans l'espace public. Mobilisations et logiques de représentation dans la France contemporaine, Doctorat de science politique. Paris: IEP.

Mouchard, Daniel (2002a), “'Politique délibérative' et logiques de mobilisation. Le cas d'Agir Ensemble contre le Chômage”, Politix, 57, 125-147.

Mouchard, Daniel (2002b), "Les mobilisations des 'sans' dans la France contemporaine: l'émergence d'un 'radicalisme autolimité”, Revue française de science politique, 4, 425-447.

Multitudes et Samizdat.net, Gênes. Multitudes en marche contre l'Empire. Paris: Reflex, 2002.

Ollitrault, Sylvie (2001), "Les écologistes français, des experts en action”, Revue française de science politique, 51(1-2), 105-130.

Patouillard, Victoire (1998), "Une colère politique: l'usage du corps dans une situation exceptionnelle”, Sociétés contemporaines, 31, 15-36.

Péchu, Cécile (2001), "Les générations militantes à Droit au logement", Revue française de science politique, 51(1-2), 73-103.

Péchu, Cécile (1996), “Quand les 'exclus' passent à l'action. La mobilisation des mal-logés”, Politix, 34, 115-134.

Pedretti, Mario (2001), La figure du désobéissant en politique. Etudes de pratique de désobéissance civile en démocratie. Paris: L'Harmattan.

Pingaud, Denis (2000), La gauche de la gauche. Paris: Seuil.

Rawls, John (1991), "Definition and Justification of Civil Disobedience", in Hugo Adam Bedau (org.), Civil Disobedience in Focus. London: Routledge.

Sainsaulieu, Ivan (1999), La contestation pragmatique dans le syndicalisme autonome. La question du modèle SUD-PTT. Paris: L'Harmattan.

Salmon, Jean-Marc (1998), Le désir de société. Des Restos du Cour au mouvement des chômeurs. Paris: La Découverte.

Siméant, Johanna (1993), "La violence d'un répertoire: les sans-papiers en grève de la faim”, in Philippe Braud (org.), La violence politique dans les démocraties européennes occidentales. Paris: L'Harmattan, 315-338.

Siméant, Johanna (1998), La cause des sans-papiers. Paris: Presses de Sciences-Po.

Sommier, Isabelle (2003), Les nouveaux mouvements contestataires à l'beure de la mondialisation. Paris: Champs Flammarion.

Sommier, Isabelle; Crettiez, Xavier (orgs.) (2002), La France rebelle. Paris: Michalon. Stallman, Richard, Introduction au logiciel libre, à la société libre. Essais choisis de Richard M. Stallman, Association pour la promotion et la recherche en informatique libre et le Manifeste GNU sur GNU.org. 
Szczepanski, Maxime (2002), "Du militantisme à la militance. Une étude microsociologique des modalités de participation des militants antimondialisation”, Regards sociologiques, 24.

Tarrow, Sidney (2000), "La contestation transnationale”, Cultures et conflits, 38/39, 187-220.

Thévenot, Laurent (1999), "Faire entendre une voix. Régimes d'engagement dans les mouvements sociaux", Mouvements, 3, 73-82.

Thoreau, Henry David (1996), Civil Disobedience. Paris: Mille et une nuits [1849].

Virno, Paolo (2001), Grammaire de la multitude. Pour une analyse des formes de vie contemporaines. Paris: Éclat et Conjunctures.

Walzer, Michael (1970), Obligations: Essays on Disobedience, War and Citizenship. Cambridge: Harvard University Press.

Wieviorka, Michel (org.) (2003), Un autre monde... Contestations, dérives et surprises dans l'antimondialisation. Paris: Balland. 